rh 19 Revue d'histoire du XIXe siècle

Société d'histoire de la révolution de 1848 et des

révolutions du XIXe siècle

14 | 1997

Cinquante ans de recherches sur 1848

\title{
"Comment naissent les révolutions"... cinquante ans après "
}

Francis Démier

(2) OpenEdition

Journals

Electronic version

URL: http://journals.openedition.org/rh19/109

DOI: $10.4000 /$ rh19.109

ISSN: $1777-5329$

Publisher

La Société de 1848

Printed version

Date of publication: 1 June 1997

ISSN: 1265-1354

Electronic reference

Francis Démier, " "Comment naissent les révolutions"... cinquante ans après " », Revue d'histoire du XIXe siècle [Online], 14 | 1997, Online since 10 September 2008, connection on 24 April 2019. URL http://journals.openedition.org/rh19/109 ; DOI : 10.4000/rh19.109

This text was automatically generated on 24 April 2019

Tous droits réservés 


\title{
"Comment naissent les révolutions"... cinquante ans après "
}

\author{
Francis Démier
}

\begin{abstract}
S
"How are Revolutions born" 50 years later What has been the influence, during half a century of historical researches, of Ernest Labrousse's famous contribution to the Centenary colloquium : "1848-1830-1789. How are Revolutions born?" The Labroussian scheme which divides only one revolution in several events that occured during the first half of the XIXth century has offered a global explanation of the revolutionary phenomenon. The local monographies, each in their own way and by constantly improving the general pattern, have defined the economic foundations of France's social realities in the XIXth century by creating a large collective thesis. After the 1980's, the major economic crisis explanation has been criticized step by step. When separated from it's economic and social roots, the 1848 revolution appeared in the eyes of historians as a plain landmark of the social groups differenciated politicizations. Through the impetus of anglo-saxon studies, the problematic of more or less stressed modernization of french economic structures and political behaviours during the last century has been privileged. The revolutionary causalities, the outline of the production connections, the various social classes are now considered in their full aspect.
\end{abstract}

Quelle a été l'influence au fil d'un demi-siècle de recherches historiques de la célèbre contribution d'Ernest Labrousse au colloque du Centenaire : " 1848-1830-1789. Comment naissent les Révolutions ? " Le schéma labroussien d'une seule révolution à plusieurs épisodes s'étendant sur la première moitié $d u \mathrm{XIX}^{\mathrm{e}}$ siècle a proposé une explication globale du phénomène révolutionnaire. Chacune à sa manière, et en affinant sans cesse le modèle général, les monographies locales, en formant comme une vaste thèse collective, ont révélé les fondements 
économiques des réalités sociales de la France du XIX siècle. À partir des années 1980, l'explication par une crise économique majeure a été peu à peu remise en cause. Coupée de ses racines économiques et sociales, la révolution de 1848 est alors apparue aux yeux des historiens comme un simple jalon de la politisation différenciée des groupes sociaux. Sous l'impulsion des études anglo-saxonnes, a été privilégiée la problématique de la modernisation plus ou moins accentuée des structures économiques et de la vie politique française au siècle dernier. Les causalités révolutionnaires, les contours des rapports de productions, les différentes classes sociales, sont aujourd'hui considérés dans toute leur complexité.

INDEX

Mots-clés: Historiographie 